\title{
Molecular and linkage analysis of type-1 protein phosphatase catalytic beta-subunit gene: lack of evidence for its major role in insulin resistance in Pima Indians
}

\author{
M. Prochazka ${ }^{1}$, H. Mochizuki ${ }^{1}$, L.J. Baier ${ }^{1}$, P.T. W. Cohen ${ }^{2}$, C. Bogardus ${ }^{1}$ \\ ${ }^{1}$ Clinical Diabetes and Nutrition Section, National Institute of Diabetes and Digestive and Kidney Diseases, National Institutes \\ of Health, Phoenix, Arizona, USA \\ ${ }^{2}$ Department of Biochemistry, Medical Research Council Protein Phosphorylation Unit, University of Dundee, Dundee, UK
}

\begin{abstract}
Summary Insulin resistance is believed to be a prediabetic condition that results from reduced rates of insulin-mediated glycogen synthesis in skeletal muscle. A decrease in activities of skeletal muscle glycogen synthase and of its regulatory enzyme type-1 protein phosphatase (PP 1) have been previously identified in insulin-resistant Pima Indians. Because the PP1 catalytic $\beta$-subunit is presumed to be the major isoform in the glycogen-bound PP1 complex, we have selected the structural gene for this subunit (PPP1CB) as a candidate for a detailed genetic analysis. We have determined the exon-intron structure of PPP1CB, and have identified a polymorphic (CA)-repeat marker (D2S1237) at this gene. No sequence abnormalities were detected in PPP1CB by Southern blot analysis or by single-stranded conformational
\end{abstract}

polymorphism analysis of all eight coding exons. Using sib-pair linkage analyses, no evidence for linkage was found between the D2S1237 marker at this locus and fasting insulin, insulin-stimulated glucose uptake in vivo, obesity, or non-insulin-dependent diabetes mellitus. Similarly, we have found no evidence for association of D2S1237 with any of these phenotypes. Based on our data we conclude that the structural gene for the PP1 catalytic $\beta$-subunit does not appear to be a major genetic determinant responsible for the PP1 abnormalities characteristic of insulin resistance in Pima Indians. [Diabetologia (1995) 38: 461-466]

Key words Insulin resistance, type- 1 protein phosphatase, PP1 $\beta$ catalytic subunit gene, Pima Indians.
Insulin resistance is associated with decreased rates of insulin-mediated glycogen synthesis in skeletal muscle, which is the major tissue responsible for peripheral glucose disposal (reviewed in [1]). Insulin resistance is predictive of the development of non-insulin-dependent diabetes mellitus (NIDDM) in Pima Indians, and family and population studies have provided evidence that it is genetically determined [2]. Because of the complexity of insulin action in skele-

Received: 30 May 1994 and in revised form: 15 September 1994

Corresponding author: Dr. M.Prochazka, Clinical Diabetes and Nutrition Section, 4212 North 16th St., Phoenix, AZ 85016, USA

Abbreviations: NIDDM, Non-insulin-dependent diabetes mellitus; PP1, type-1 protein phosphatase; PPP1CB, type-1 protein phosphatase catalytic $\beta$-subunit gene; SSCP, single-stranded conformational polymorphism; PCR, polymerase chain reaction. tal muscle, further analysis of the genetic basis for insulin resistance in Pima Indians required identification of a specific biochemical abnormality as a phenotypic marker for the selection of a particular candidate gene.

In previous efforts to better define insulin resistance at the biochemical level in Pima Indians, insulin effects on several enzymatic activities involved in the control of glycogen metabolism in skeletal muscle were compared between insulin-resistant and -sensitive subjects $[3,4]$. These studies demonstrated reduced basal and insulin-stimulated activity of total and glycogen-bound type- 1 protein phosphatase (PP1) in insulin-resistant Pima Indians. Insulin stimulation of glycogen synthase, which is activated by PP1, was also decreased in insulin-resistant subjects. Because PP1 has a key regulatory role in glycogen synthesis, we have selected this enzyme for detailed genetic analysis. 
Glycogen-bound PP1 activity in skeletal muscle is determined by a catalytic subunit non-covalently complexed with the targeting regulatory G-subunit [5], and a defect in either component could cause the biochemical alterations observed in Pima Indians. Three structurally similar, but genetically distinct isoforms of the PP1 catalytic subunit (PP1 $\alpha, \mathrm{PP} 1 \beta$, and PP1 $\gamma$ ) were identified in different mammalian tissues including skeletal muscle [6-9]. In vitro studies using mostly rabbit protein preparations indicated that each catalytic isoform can complex with the Gsubunit [10], but PP1 $\beta$ appeared to be the predominant glycogen-bound form in rabbit skeletal muscle [11]. Because of the high phylogenetic conservation of PP1 catalytic isoforms [12], the human gene coding for the $\beta$-subunit (PPP1CB) represented a primary candidate for further investigation of the glycogen-associated PP1 abnormalities, and of the genetic basis of insulin resistance in Pima Indians.

Recent cloning of the full-length human PP1 $\beta$ cDNA and mapping of PPP1CB to chromosome 2 [9] enabled us to screen this gene directly in Pima Indians for sequence alteration(s) that would correlate with the biochemical abnormalities. Here we describe the genomic organization of PPP1CB, the identification of a linked polymorphic (CA)-repeat marker, and present the results of exon screening, and linkage and association analyses of this gene with regard to the insulin-resistant phenotype in Pima Indians.

\section{Subjects, materials and methods}

Subjects and DNA samples. The subjects are members of the Gila River Indian Community who have participated in NIDDM studies since 1965 [2]. Beginning at the age of 5 years, participants are asked to come to an outpatient clinic every 2 years for examination. Some of these individuals are further admitted to the clinical research ward for several tests including oral glucose tolerance test and a two-step hyperinsulinaemic, euglycaemic clamp to measure insulin action in vivo $[2,13]$.

Individual genomic DNAs were isolated from Epstein-Barr virus-transformed lymphocyte cultures, or directly from peripheral kocytes as described previously [13].

Caucasian DNAs, and DNA from the somatic cell hybrid 24HL5-4 (NA 10826B) containing human chromosome 2 were obtained from the NIGMS repository (Coriell Institute, Camden, N.J. USA). A subset of the Caucasian DNA samples is also a part of the CEPH reference collection [14].

PPP1CB YAC genomic clone $(y P P 1 \beta)$. The isolation of a PPP1CB YAC clone (referred to as $\mathrm{YPP} 1 \beta$ in this paper) has been described previously [9]. The size of yPP $1 \beta$ was determined by pulsed field gel electrophoresis using the CHEF DRII apparatus (Biorad, Richmond, Calif., USA) according to the manufacturer's protocol. A Southern blot of the gel was hybridized with PP1 $\beta$ cDNA probe as described below. The size of the clone (approximately 310 kilobases) was estimated by comparison with a lambda ladder PFG marker
(New England Biolabs, Beverly, Mass., USA) run on the same gel.

$P C R$ amplification and sequencing of exon-intron boundaries. Polymerase chain reactions (PCR) were performed in Gene Amp 9600 thermal cycler (Perkin Elmer, Norwalk, Conn., USA) using reagents from the same supplier. Unless otherwise indicated, "hot-start" PCR was utilized to minimize amplification of non-specific products. Typically, the reaction volume was $25 \mu \mathrm{l}$ and consisted of $1 \times$ PCR buffer with $1.5 \mathrm{mmol} / 1 \mathrm{MgCl}_{2}, 0.2 \mathrm{mmol} / 1$ of each dNTP, $6 \mathrm{pmol}$ of each primer, and approximately $250 \mathrm{pg}$ of yPP1 $\beta$ DNA. After an initial heating step at $94^{\circ} \mathrm{C}$ for $5 \mathrm{~min}$, the temperature was ramped to $80^{\circ} \mathrm{C}$ and $0.625 \mathrm{U}$ of AmpliTaq DNA polymerase diluted in $1 \times$ PCR buffer was added to each sample, followed by 30 cycles of $45 \mathrm{~s}$ at $94^{\circ} \mathrm{C}, 30 \mathrm{~s}$ at $57^{\circ} \mathrm{C}$, and $4 \mathrm{~min}$ at $72^{\circ} \mathrm{C}$ with $10 \mathrm{~s}$ added to the extension time in every cycle. The products were analysed by agarose gel electrophoresis.

Initial sets of PCR primers were designed from the PP1 $\beta$ cDNA sequence at positions within putative exons predicted from the structure of a gene encoding the highly homologous PP1 catalytic $\gamma$-subunit in humans (S. Norman, unpublished data). When a predicted intron could not be amplified, or the quantity of a large PCR product was insufficient for direct sequencing, Alu-PCR or inverse PCR techniques were utilized for analysis of the corresponding exon-intron boundaries.

Alu-PCR involved the use of one PP1 $\beta$ cDNA-based primer (presumably within an exon) in combination with a primer complementary to either the $5^{\prime}$ or $3^{\prime}$ end of Alu elements [15], which are the most ubiquitous short repeats in the human genome. Because large introns, such as those found in PPP1CB (see Results) are more likely to contain Alu sequence(s), this PCR strategy permitted successful amplification of most exon-intron boundaries.

For inverse PCR (IPCR), total YAC DNA was digested with a 4-base cutting restriction endonuclease which, based on the cDNA sequence, had no recognition site within a predicted exon. Depending on the region of interest, Msp I, Hae III, Hinc II, or Rsa I were used. Digested DNA was phenol/chloroform extracted, and ligated for $15 \mathrm{~h}$ at a low concentration $(0.05 \mu \mathrm{g} / \mathrm{ml})$ to facilitate circularization rather than concatamerization of the fragments. After precipitation, the ligated DNA was subjected to "hot-start" PCR for 35-40 cycles as described above using pairs of oligonucleotides designed to prime DNA polymerization in an inverse orientation in regard to the original (linear) genomic template.

DNA sequences were determined by the dideoxynucleotide termination method using a cycle sequencing kit (GIBCO-BRL, Gaithersburg, Md., USA). Most of the PCR products were sequenced either directly or after gel purification; larger products $(>2 \mathrm{~kb})$ were subcloned into the pCRII vector using the TA cloning kit (Invitrogen, San Diego, Calif., USA) prior to sequencing. Information on exon-intron sequences was submitted to GenBank. Oligonucleotide primers were synthesized on a 392 DNA Synthesizer (Applied Biosystems, Foster City, Calif., USA).

Typing of SSCP. Individual exons were PCR amplified with primer sets designed from the flanking intron sequences (Table 1). Typically, $50 \mathrm{ng}$ of DNA in $10 \mu \mathrm{l}$ of PCR reagent mixture (see above) was subjected to 26 cycles ( 29 for exon 1 ), each consisting of $30 \mathrm{~s}$ at $94^{\circ} \mathrm{C}, 1 \mathrm{~min}$ at $55^{\circ} \mathrm{C}\left(57^{\circ} \mathrm{C}\right.$ for exon 1), and $30 \mathrm{~s}$ at $72^{\circ} \mathrm{C}$. Subsequently, a $5 \mu$ l aliquot of the product was mixed with $1 \mu \mathrm{l}$ of $1 \times$ PCR buffer containing $0.05 \mathrm{U}$ of AmpliTaq DNA polymerase plus $0.3 \mathrm{pmol}$ of both primers, each $5^{\prime}$ end-labelled with ${ }^{32} \mathrm{P}$. Following an additional amplification step, the samples were mixed with equal volume 
Table 1. Primer pairs for SSCP analysis of PPP1CB exons

\begin{tabular}{|c|c|c|c|c|c|c|c|c|c|c|c|}
\hline Designation $^{\mathrm{a}}$ & Exon & Sequen & $\mathrm{e}\left(5^{\prime} \rightarrow 3\right.$ & & & & & & & & $\begin{array}{l}\text { Product Size } \\
\text { (bp) }\end{array}$ \\
\hline $\begin{array}{l}\text { BETA-18 } \\
\text { BEX-1A2 }\end{array}$ & 1 & $\begin{array}{l}\text { GGA } \\
\text { GCG }\end{array}$ & $\begin{array}{l}\text { GAG } \\
\text { GCC }\end{array}$ & $\begin{array}{l}\text { TCT } \\
\text { AGG }\end{array}$ & $\begin{array}{l}\text { GTG } \\
\text { CGC }\end{array}$ & $\begin{array}{l}\text { CCG } \\
\text { GCA }\end{array}$ & $\begin{array}{l}\mathrm{ACA} \\
\mathrm{CT}\end{array}$ & A & & & 92 \\
\hline $\begin{array}{l}\text { BEX-2S } \\
\text { BEX-2A }\end{array}$ & 2 & $\begin{array}{l}\text { TTG } \\
\text { AGG }\end{array}$ & $\begin{array}{l}\text { AAA } \\
\text { AAA }\end{array}$ & $\begin{array}{l}\text { GAT } \\
\text { AAC }\end{array}$ & $\begin{array}{l}\text { TAT } \\
\text { ATG }\end{array}$ & $\begin{array}{l}\text { TAT } \\
\text { ATT }\end{array}$ & $\begin{array}{l}\text { GAG } \\
\text { CAA }\end{array}$ & $\begin{array}{l}\text { TAA } \\
\text { AAG }\end{array}$ & $\begin{array}{l}\text { ATT } \\
\text { AG }\end{array}$ & $\mathrm{TT}$ & 242 \\
\hline $\begin{array}{l}\text { BEX-3S } \\
\text { BETA-23R }\end{array}$ & 3 & $\begin{array}{l}\text { AAT } \\
\text { CTG }\end{array}$ & $\begin{array}{l}\text { CAT } \\
\text { GAT }\end{array}$ & $\begin{array}{l}\text { TTC } \\
\text { ATT }\end{array}$ & $\begin{array}{l}\text { ATA } \\
\text { TGA }\end{array}$ & $\begin{array}{l}\text { GAA } \\
\text { TTT }\end{array}$ & $\begin{array}{l}\text { GCT } \\
\text { TAT }\end{array}$ & $\begin{array}{l}\text { GCT } \\
\text { AAG }\end{array}$ & $\begin{array}{l}\mathrm{TA} \\
\mathrm{CC}\end{array}$ & & 225 \\
\hline $\begin{array}{l}\text { BETA-9 } \\
\text { BEX-3A1 }\end{array}$ & 3 & $\begin{array}{l}\text { CAG } \\
\text { CTG }\end{array}$ & $\begin{array}{l}\text { AAG } \\
\text { AAT }\end{array}$ & $\begin{array}{l}\text { CCA } \\
\text { CAA }\end{array}$ & $\begin{array}{l}\text { ACT } \\
\text { AGC }\end{array}$ & $\begin{array}{l}\text { ATC } \\
\text { AAC }\end{array}$ & $\begin{array}{l}\text { TTT } \\
\text { TCT }\end{array}$ & $\begin{array}{l}\text { TCT } \\
\text { TCT }\end{array}$ & $\begin{array}{l}\text { TA } \\
\text { G }\end{array}$ & & 253 \\
\hline $\begin{array}{l}\text { BEX-4S } \\
\text { BEX-4A }\end{array}$ & 4 & $\begin{array}{l}\text { TTG } \\
\text { AGA }\end{array}$ & $\begin{array}{l}\text { AGA } \\
\text { AAA }\end{array}$ & $\begin{array}{l}\text { TAA } \\
\text { AAA }\end{array}$ & $\begin{array}{l}\text { CTG } \\
\text { AAA }\end{array}$ & $\begin{array}{l}\text { ATG } \\
\text { TCT }\end{array}$ & $\begin{array}{l}\text { AGA } \\
\text { GTA }\end{array}$ & $\begin{array}{l}\text { ACA } \\
\text { AGG }\end{array}$ & $\begin{array}{l}\mathrm{G} \\
\mathrm{CAA}\end{array}$ & & 205 \\
\hline $\begin{array}{l}\text { BEX-5S } \\
\text { BEX-5A2 }\end{array}$ & 5 & $\begin{array}{l}\text { AAT } \\
\text { CAA }\end{array}$ & $\begin{array}{l}\text { TTT } \\
\text { GTT }\end{array}$ & $\begin{array}{l}\text { TAG } \\
\text { CAA }\end{array}$ & $\begin{array}{l}\text { CTG } \\
\text { ATA }\end{array}$ & $\begin{array}{l}\text { TTA } \\
\text { TGA }\end{array}$ & $\begin{array}{l}\text { GTA } \\
\text { AAA }\end{array}$ & $\begin{array}{l}\text { CTA } \\
\text { CAC }\end{array}$ & $\begin{array}{l}\text { TGT } \\
\text { TTT }\end{array}$ & & 172 \\
\hline $\begin{array}{l}\text { BEX-6S } \\
\text { BEX-6A }\end{array}$ & 6 & $\begin{array}{l}\text { GTG } \\
\text { CCC }\end{array}$ & $\begin{array}{l}\text { CTA } \\
\text { CAA }\end{array}$ & $\begin{array}{l}\text { TAT } \\
\text { AAA }\end{array}$ & $\begin{array}{l}\text { TCT } \\
\text { AAA }\end{array}$ & $\begin{array}{l}\text { ATA } \\
\text { GAA }\end{array}$ & $\begin{array}{l}\text { AAT } \\
\text { AGA }\end{array}$ & $\begin{array}{l}\text { CTG } \\
\text { AAA }\end{array}$ & $\begin{array}{l}\text { TAA } \\
\text { AAG }\end{array}$ & & 266 \\
\hline $\begin{array}{l}\text { BEX-7S } \\
\text { BEX-7A }\end{array}$ & 7 & $\begin{array}{l}\text { TAG } \\
\text { TAT }\end{array}$ & $\begin{array}{l}\text { TAT } \\
\text { TAG }\end{array}$ & $\begin{array}{l}\text { AGA } \\
\text { ATT }\end{array}$ & $\begin{array}{l}\text { TGG } \\
\text { TCT }\end{array}$ & $\begin{array}{l}\text { TTC } \\
\text { AGT }\end{array}$ & $\begin{array}{l}\text { AGA } \\
\text { TCT }\end{array}$ & $\begin{array}{l}\text { ATT } \\
\text { TAT }\end{array}$ & $\begin{array}{l}\text { AC } \\
\text { ATA }\end{array}$ & $\mathrm{TT}$ & 241 \\
\hline $\begin{array}{l}\text { BEX-8S } \\
\text { BETA-14R }\end{array}$ & 8 & $\begin{array}{l}\text { ACA } \\
\text { ATG }\end{array}$ & $\begin{array}{l}\text { ATT } \\
\text { AAG }\end{array}$ & $\begin{array}{l}\text { TTC } \\
\text { TAT }\end{array}$ & $\begin{array}{l}\text { TTA } \\
\text { GTC }\end{array}$ & $\begin{array}{l}\text { ACT } \\
\text { CTT }\end{array}$ & $\begin{array}{l}\text { TCT } \\
\text { AAC }\end{array}$ & $\begin{array}{l}\text { GTA } \\
\text { AAA }\end{array}$ & $\begin{array}{l}\text { CAT } \\
\text { TC }\end{array}$ & & 217 \\
\hline
\end{tabular}

${ }^{\mathrm{a}} \mathrm{BEX}$ primers were designed from intronic sequences flanking the $5^{\prime}$ end (sense primer, S) and the $3^{\prime}$ end (antisense primer, A) of the respective exons. BETA primers were designed either from the $5^{\prime}$ non-coding (BETA-18) or $3^{\prime}$ non-coding

of sequencing dye, heat denatured, and electrophoresed through $5 \%$ polyacrylamide gels (acrylamide : bisacrylamide $=75: 1$ ) with and without $5 \%$ glycerol. Because of its small size, exon 1 was also analysed on a $7 \%$ polyacrylamide gel. Electrophoresis ( $5 \mathrm{~W}$ constant power) was performed at room temperature and at $4^{\circ} \mathrm{C}$ in $0.5 \times \mathrm{TBE}(1 \times=90 \mathrm{mmol} / 1$ Tris, $90 \mathrm{mmol} / 1$ Boric Acid, $2.5 \mathrm{mmol} / 1$ EDTA) running buffer. Autoradiography was performed for $16-18 \mathrm{~h}$ at $-70^{\circ} \mathrm{C}$.

Dinucleotide repeats and polymorphism typing. (CA) and (GT) dinucleotide repeats were selectively isolated from the human genomic DNA insert in $\mathrm{yPP} 1 \beta$ by a modification of Alu-PCR using one of the Alu-specific primers [15] in combination with a $\mathrm{C}_{4}(\mathrm{CA})_{11}$ or $\mathrm{G}_{4}(\mathrm{GT})_{11}$ oligomer [16]. DNA products were gel-purified, reamplified, and subcloned into pCRII for sequencing. Because only the flanking sequence for one end of a given (CA)- or (GT)-repeat was obtained in this initial screen, unique primers were designed from the sequenced region for a subsequent IPCR (performed as described above) to isolate the DNA segment flanking the opposite end of the repeat. The chromosomal location of each repeat was verified by amplification from DNA of the human/Chinese hamster somatic cell hybrid 24HL5-4 containing chromosome 2 as the sole human chromosome.

Amplifications of D2S1237 were performed in a 5- $\mu 1$ PCR volume containing $50 \mathrm{ng}$ DNA, $1 \times$ PCR buffer adjusted to $3 \mathrm{mmol} / 1 \mathrm{MgCl}_{2}, 0.2 \mathrm{pmol}^{32} \mathrm{P} 5^{\prime}$ end-labelled primer BETAMS10 [5' $\rightarrow 3^{\prime}:$ GCAATCCCTGACAGCTAATG], 1 pmol unlabelled primer BETA-MS18 [GACAATCAATTTAAAAAATGGGCAAATA], and $0.15 \mathrm{U}$ AmpliTaq DNA polymerase. Samples were heated for $3 \mathrm{~min}$ at $94^{\circ} \mathrm{C}$, followed by 27 cycles of $30 \mathrm{~s}$ at $94^{\circ} \mathrm{C}, 1 \mathrm{~min}$ at $55^{\circ} \mathrm{C}$, and $45 \mathrm{~s}$ at $72^{\circ} \mathrm{C}$. Products were mixed with an equal volume of sequencing dye, heat denatured, and separated on a $6 \%$ sequencing gel. Autoradiography was performed for $4-16 \mathrm{~h}$ at room temperature. A sequencing ladder was run on each gel for correct
(BETA-14R) sequences of the cDNA, or from the coding sequences within exon 3 (BETA-23R, BETA-9) to perform the SSCP analysis of this large exon (see Table 2) on two smaller overlapping segments

band sizing, and the results were scored independently by two investigators. Information about D2S1237 has been deposited in the Genome Data Base, and in GenBank (accession numbers G00-304-440 and U10997, respectively).

Southern blot analysis. Aliquots of genomic DNA $(10 \mu \mathrm{g}) \mathrm{di}-$ gested with Eco RI or Sac I were subjected to agarose gel electrophoresis and blotted onto GeneScreen nylon membrane as described [17]. The hybridization probe was a mixture of three overlapping PCR fragments which represented the full-length cDNA, plus the $5^{\prime}$ and $3^{\prime}$ untranslated regions. The probe fragments were amplified from a Caucasian skeletal muscle cDNA library (5'Stretch library, number HL1124n, Clontech Laboratories, Palo Alto, Calif., USA), and their identity was verified by sequencing of approximately 100 bases from each end. Probe labelling and hybridization conditions were as described in [17] with a final post-hybridization wash performed at $65^{\circ} \mathrm{C}$ in $0.1 \times \mathrm{SSC} / 0.1 \% \mathrm{SDS}$.

Linkage and association analyses. Linkage analyses were performed on sib-pairs with the Statistical Analysis for Genetic Epidemiology package (SAGE, see Acknowledgements). With this method, linkage is assessed from the correlation between the squared sibling difference in a trait and the proportion of alleles identical by descent at a given locus. A onetailed Student's $t$-test was used to test the significance of the correlation. Only $p<0.001$ was considered significant as suggested by Ott [18]. Association analyses were performed by multiple linear regression analysis for continuously distributed quantitative phenotypes, and by logistic regression and chi-square analysis for dichotomous phenotypes (Statistical Analysis Systems, SAS Institute, Cary, N.C., USA). Definitions of quantitative phenotypes and adjustments of co-variates by linear regression analysis were as described previously [13]. 
Table 2. Splice junctions and sizes of PPP1CB exons and introns

\begin{tabular}{|c|c|}
\hline $\begin{array}{l}\text { Exon } \\
\text { (No.; size in bp) }\end{array}$ & $\begin{array}{l}\text { Intron } \\
\text { (No.; size in } \mathrm{kb} \text { ) }\end{array}$ \\
\hline $\begin{array}{l}\text { ATG } \ldots\left(\mathbf{I} ; 52^{\mathrm{a}}\right) \ldots \\
\text { Met } \\
1\end{array}$ & $\begin{array}{l}\text { GAG G]gtgagt. . } \\
\text { Glu V } \\
17\end{array}$ \\
\hline $\begin{array}{c}\text {. atcgtttgtcag[TA CGA .. (II; 132) ... } \\
\text { al Arg } \\
19\end{array}$ & $\begin{array}{l}\text { TGT G]gtatgt . . (ii; > 6.0).. } \\
\text { Cys G } \\
61\end{array}$ \\
\hline. $\operatorname{ttctctttttag}\left[\begin{array}{c}\text { GA GAT } \\
l y \\
63\end{array}\right.$ & $\begin{array}{l}\text { GAA T]gtaagt . . (iii; 3.8) . } \\
\text { Glu C } \\
138\end{array}$ \\
\hline. ttettttacag [GC AAA ... IV; 105) ... & $\begin{array}{l}\text { GGA G]gtagac . . (iv; 2.1) . } \\
\text { Gly G } \\
173\end{array}$ \\
\hline ttttatttatag [GA TTG.. ${ }_{l y}^{\text {Leu }}(\mathrm{V} ; 72) \ldots$. & $\begin{array}{l}\text { ACA G]gtaagt } \ldots(\mathrm{v} ; 5.5) \ldots \\
T h r \quad G \\
197\end{array}$ \\
\hline $\begin{array}{c}. \text { tgtcctttaaag [GT TTG. . (VI; 152)... } \\
\text { ly Leu } \\
199\end{array}$ & $\begin{array}{l}\text { CAG]gtatga .. (vi; } 6.0) \ldots \\
\text { Gln } \\
248\end{array}$ \\
\hline .. ttcctttgacag $\left[\begin{array}{c}\text { GTG . . . . . (VII; } 135) \ldots \\
249\end{array}\right.$ & $\begin{array}{l}\text { CAG]gt atga . . (vii; 6.0) . } \\
\text { Gln } \\
293\end{array}$ \\
\hline $\begin{array}{c}. \text { atttactttaag }\left[\text { ATA ..... (VIII; } 102^{\mathrm{a}}\right) . \\
\text { Ile } \\
294\end{array}$ & $\begin{array}{l}\text { AGG tga ... } \\
\text { Arg Stop } \\
327\end{array}$ \\
\hline
\end{tabular}

Coding sequences are in bold capital letters with the amino acid residues (in italics) and codon numbers corresponding to the published PP1 $\beta$ sequence [9]. Non-coding sequences are in lower-case letters. Splice donor $(g t)$ and splice acceptor $(a g)$ sites are also italicized; splicing boundaries are indicated with brackets. Complete sequences were deposited in GenBank under accession numbers U10998-U11005

a Sizes include only the coding parts of the first and last exon, respectively

\section{Results}

Exon-intron structure of $P P P 1 C B$. The exon-intron organization of PPP1CB was determined by the combination of different PCR-based techniques using the yPP1 $\beta$ genomic clone as described in Methods. Our data revealed that the coding part of PPP1CB is represented by eight exons distributed over at least $30 \mathrm{~kb}$ of genomic DNA. Using cDNA-based primers, we were able to directly amplify the last five introns ranging in size from 2.5 to $6 \mathrm{~kb}$ as estimated by agarose gel electrophoresis (Table 2). Because the first and second intron could not be amplified with cDNA-specific primers alone (the corresponding exon-intron boundaries were determined by AluPCR or IPCR), we conclude that their sizes exceed $6 \mathrm{~kb}$, which appeared to be the upper limit for efficient PCR amplification under our conditions. The sequences of all exon-intron junctions (Table 2) were in agreement with the GT-AG consensus for donor and acceptor splice sites of eukaryotic genes [19]. The contiguity of each predicted exon (i.e. the absence of additional introns within the coding sequen- ces) was further verified in the SSCP analysis described below and by direct sequencing. Similarly, the absence of an intron in the long $3^{\prime}$ non-coding region of this gene was confirmed by direct PCR from yPP1 $\beta$ and from total human genomic DNA which yielded a $2.4 \mathrm{~kb}$ product predicted from the cDNA sequence.

SSCP analysis. To screen for nucleotide variations in the coding sequences and in the splicing exon-intron junctions of PPP1CB, we have designed sets of primers from intron sequences for PCR amplification of individual exons (Table 1) which were subjected to SSCP analysis. We have selected DNA from 20 insulin-resistant and 20 insulin-sensitive Pima Indians, none of whom were first-degree relatives. As a control, a Caucasian DNA sample was also included in each assay. To maximize the sensitivity of this technique, we have used four different electrophoresis conditions (gels with and wihtout glycerol, run at room temperature and at $4^{\circ} \mathrm{C}$ ) as described in Methods. The only detected sequence variant was a silent substitution at the $\operatorname{Gln}^{67}$ codon $(\mathrm{CA} A \rightarrow \mathrm{CA} G)$ in exon 3 in one insulin-resistant Pima Indian (CAA/ CAG heterozygote), and in the Caucasian control subject (CAG/CAG homozygote). This polymorphism was identical with that reported previously in Caucasians [20].

Southern blot analysis of PP1CB. To search for deletions or insertions in PPP1CB, Southern blot analysis was performed on genomic DNA samples from seven insulin-sensitive, six non-diabetic insulin-resistant, and 17 diabetic Pima Indians, as well as one Caucasian control subject. The blots were constructed with DNA digested either with Sac I or with Eco $\mathrm{RI}$, and probed under high stringency conditions as described in Methods. Both endonucleases produced several invariant genomic fragments (Sac I: $4.5 \mathrm{~kb}$, $9.5 \mathrm{~kb}, 19 \mathrm{~kb},>23 \mathrm{~kb}$; Eco RI: $1.2 \mathrm{~kb}, 4 \mathrm{~kb}, 5.5 \mathrm{~kb}$, $9 \mathrm{~kb}, 17 \mathrm{~kb}$ ) with no evidence for a gross stuctural alteration of the gene (not shown). We have also observed an Eco RI restriction fragment length polymorphism $(6 \mathrm{~kb} / 12 \mathrm{~kb})$ which showed no correlation with insulin-resistance or NIDDM, and was apparently caused by a variation in an Eco RI site in intron 6 as determined by separate hybridization of the blots with exon-specific probes (not shown).

Identification of a PPP1CB-linked polymorphic mar$k e r$, and linkage and association analyses. Of the four (CA) repeats isolated from yPP1 $\beta$, a (CA $)_{18}$ microsatellite designated D2S1237 showed informative polymorphism. Five alleles were observed in 830 Pima Indians, whereas only four alleles were detected in 56 unrelated Caucasians (Table 3 ). To avoid erroneous estimates in the Pima Indians due to multiple genotype contributions by first-degree relatives from individual families, we have also calculated allele fre- 
M.Prochazka et al.: PP1 $\beta$ gene and insulin resistance

Table 3. D2S1237 polymorphism in Pima Indians and Caucasians

\begin{tabular}{llll}
\hline Allele & Size (bp) & \multicolumn{2}{l}{ Frequency } \\
\cline { 3 - 4 } & & Pimas $^{\mathrm{a}}$ & Caucasians $^{\mathrm{b}}$ \\
\hline 1 & 154 & 0.056 & 0.044 \\
2 & 152 & 0.536 & 0.438 \\
3 & 150 & 0.004 & 0.080 \\
4 & 148 & 0.401 & 0.438 \\
5 & 142 & 0.003 & 0.000 \\
Heterozygosity & & 0.550 & 0.625 \\
\hline
\end{tabular}

${ }^{a}$ Estimated from 830 Pima Indians (see text for details)

${ }^{b}$ Estimated from 56 unrelated Caucasians

quencies from parents only $(n=183)$. These frequencies $(0.0066,0.538$, and 0.396 for allele 1,2 , and 4 , respectively) were very close to the calculations made from all 830 Pima subjects indicating that the numbers in Table 3 reflect correct estimates, except that alleles 3 and 5 were rare enough that they were not observed in the smaller group.

Linkage analyses with insulin action or adiposity were performed on 192 non-diabetic sib-pairs on which fasting insulin data, measurements of insulinstimulated glucose uptake (as determined by the hyperinsulinaemic, euglycaemic clamp), as well as information about body mass index and percentage of body fat were available. No linkage was found between these phenotypic parameters and D2S1237. Similarly, we have found no linkage of this marker with NIDDM by analysis of 705 sib-pairs including participants in the outpatient study (see Subjects and methods). We have also performed association analyses of D2S1237 with parameters of insulin action and obesity (137 non-diabetic subjects), and with NIDDM (846 subjects). We did not detect association of any of these phenotypes with the marker.

\section{Discussion}

Decreased total and glycogen-bound PP1 activity in skeletal muscle in the basal state and after insulin stimulation was previously associated with insulin resistance in Pima Indians. Based on the current knowledge of the protein components determining the glycogen-bound PP1 enzymatic activity, we have chosen the catalytic $\beta$-subunit structural gene PPP1CB on chromosome 2 for further analysis.

In this study, we have undertaken a systematic molecular and linkage analysis of PPP1CB to search for evidence of sequence alteration(s) that would correlate with the observed PP1 biochemical abnormalities in insulin-resistant Pima Indians. Using various PCRbased techniques, we have determined the exon structure of PPP1CB, and sequenced the corresponding exon-intron boundaries. It is of interest that the three most highly conserved sections of protein phosphata- ses predicted to be essential for catalytic activity [21] are encoded by a single exon (No.3) in PPP1CB, as well as in the gene encoding the PP1 $\alpha$ catalytic subunit (PPP1CA; M. Prochazka, unpublished data). However, comparison of intron positions in the PPP1CB gene with those in the human PPP2CA and PPP2CB genes [22] shows that the positions of introns 1,2, and 3 of PPP1CB are not conserved in the PPP2 genes, although the position of intron 5 is identical, and introns 4,6 , and 7 are in similar locations.

We have used SSCP which is a rapid and sensitive technique used routinely to screen for single nucleotide changes detected as differences in sequence-dependent electrophoretic mobilities of single-stranded DNA. By performing this assay under four different conditions to maximize its sensitivity for the analysis of all PPP1CB coding sequences and exon-intron splice junctions, we have detected only a silent $\mathrm{A} \rightarrow \mathrm{G}$ substitution at the $\mathrm{Gln}^{67}$ codon in exon 3 which corresponds to a previously reported polymorphism in Caucasians [20]. No other base changes were found that would predict a change in the protein sequence. DNA samples from a small subset of insulin-resistant, insulin-sensitive, and diabetic individuals were also subjected to Southern blot analysis revealing no evidence for gross alterations of the gene. The observed Eco RI polymorphism was apparently caused by a sequence variation in one of the intronic Eco RI sites.

To complement the SSCP analysis which was limited to PPP1CB coding sequences, we have isolated the polymorphic D2S1237 marker for linkage and association studies of this genomic region. Although the exact position of D2S1237 within the genomic insert of $y P P 1 \beta$ is not known, the size of this clone limits the maximal physical distance between the marker and PPP1CB to less than $310 \mathrm{~kb}$. Using sib-pair linkage analyses we have found no evidence for linkage of D2S1237 with insulin action, obesity, or NIDDM. Similarly, we have found no evidence for association with these phenotypes.

We conclude that alterations in the PPP1CB gene do not appear to be a major cause of PP1 abnormalities or impaired insulin action characteristic of Pima Indians. This negative finding leaves the structural gene for the targeting G-subunit as the next likely candidate for genetic analysis of the biochemical PP1 abnormalities in insulin-resistant Pima Indians. The lack of evidence for PPP1CB involvement in insulin resistance in Pima Indians does not preclude its potential role in the pathogenesis of impaired insulin action in other populations. Knowledge of PPP1CB genomic structure, and identification of a new linkage marker should facilitate testing other population groups.

Acknowledgements. The authors would like to thank Dr. S. Norman (Barrow Neurological Institute of St.Joseph's Hospital and Medical Center, Phoenix, AZ) for unpublished infor- 
mation about exon organization of the gene encoding the PP1 $\gamma$ isoform, and Ms. N. Riebow for the synthesis of DNA primers. The sib-pair analyses were performed by using the Statistical Analysis for Genetic Epidemiology program package, which is supported by a U.S. Public Health Service Resource Grant (1P41RR03655) from the Division of Research Resources, National Institutes of Health.

\section{References}

1. DeFronzo RA, Bonadonna RC, Ferrannini E (1992) Pathogenesis of NIDDM. A balanced overview. Diabetes Care Reviews 15: 318-368

2. Bogardus C, Lillioja S, Bennett PH (1991) Pathogenesis of NIDDM in Pima Indians. Diabetes Care 14 [Suppl 3]: 685-690

3. Mott DM, Kida Y, Nyomba BL (1993) Human skeletal muscle, type-1 protein phosphatase and insulin resistance. Adv Prot Phosphatases 7: 413-427

4. Kida Y, Esposito-Del Puente A, Bogardus C, Mott DM (1990) Insulin resistance is associated with reduced fasting and insulin-stimulated glycogen synthase phosphatase activity in human skeletal muscle. J Clin Invest 85: 476-481

5. Cohen P (1989) The structure and regulation of protein phosphatases. Ann Rev Biochem 58: 453-508

6. Barker HM, Jones TA, da Cruz e Silva EF, Spurr NK, Sheer D, Cohen PTW (1990) Localization of the gene encoding type 1 protein phosphatase catalytic subunit to human chromosome band 11q13. Genomics 7: 159-166

7. Barker HM, Craig SP, Spurr NK, Cohen PTW (1993) Sequence of protein serine/threonine phosphatase 1 gamma and localisation of the gene (PPP1CC) encoding it to chromosome bands 12q24.1-q24.2. Biochim Biophys Acta 1278: 228-233

8. Shima H, Hatano Y, Chun Y-S et al. (1993) Identification of PP1 catalytic subunit isotypes in various rat tissues. Biochim Biophys Res Comm 192: 1289-1296

9. Barker HM, Brewis ND, Street AJ, Spurr NK, Cohen PTW (1994) Three genes for protein phosphatase I map to different human chromosomes: sequence, expression and gene localisation of protein serine/threonine phosphatase 1 beta (PPP1CB). Biochim Biophys Acta 1220: 212-218

10. Alessi DR, Street AJ, Cohen P, Cohen PTW (1993) Inhibitor-2 functions like a chaperone to fold three expressed isoforms of mammalian protein phosphatase- 1 into a confor- mation with the specificity and regulatory properties of the native enzyme. Eur J Biochem 213: 1055-1066

11. Dombrádi V, Axton JM, Brewis ND, da Cruz e Silva EF, Alphey L, Cohen PTW (1990) Drosophila contains three genes that encode distinct isoforms of protein phosphatase 1. Eur J Biochem 194: 739-745

12. Cohen PTW (1990) The molecular biology of protein serine/threonine phosphatases regulating metabolism. In: Randle PJ, Bell J, Scott J (eds) Genetics and Human Nutrition. John Libbey, London, pp 27-40

13. Prochazka M, Lillioja S, Tait JF et al. (1993) Linkage of chromosomal markers on $4 \mathrm{q}$ with a putative gene determining maximal insulin action in Pima Indians. Diabetes 42: 514-519

14. Spurr NK (1992) Standards for reporting alleles at highly polymorphic loci: a proposal. Human Molecular Genetics 1: $211-212$

15. Tagle DA, Collins FS (1992) An optimized Alu-PCR primer pair for human-specific amplification of YACs and somatic cell hybrids. Human Molecular Genetics 1: 121-122

16. Pandolfo $M$ (1992) A rapid method to isolate $(G T)_{n}$ repeats from yeast artificial chromosomes. Nucleic Acids Res 20: 1154

17. Prochazka M, Serreze DV, Worthen SM, Leiter EH (1989) Genetic control of diabetogenesis in NOD/Lt mice: development and analysis of congenic stocks. Diabetes 38: 1446-1455

18. Ott J (1991) Methods of linkage analysis: nonparametric approaches. In: Analysis of human genetic linkage (revised ed) Johns Hopkins University Press, Baltimore, pp 77-80

19. Breathnach R, Chambon P (1981) Organization and expression of eukaryotic split genes coding for proteins. Ann Rev Biochem 50: 349-383

20. Bjorbaek C, Echwald S, Richmond K et al. (1993) Variants in the promoter and coding sequence of genes encoding key proteins in insulin stimulated glycogen synthesis of muscle from NIDDM patients. Diabetologia 36: A83 (Abstract)

21. Cohen PTW, Cohen P (1989) Discovery of a protein phosphatase activity encoded in the genome of bacteriophage $\lambda$. Biochem J 260: 931-934

22. Khew-Goodhall Y, Mayer RE, Maurer F, Stone SR, Hemmings BA (1991) Structure and transcriptional regulation of protein phosphatase $2 \mathrm{~A}$ catalytic subunit genes. Biochemistry 30: 89-97 